УДК 342.922

DOI https://doi.org/10.32849/2663-5313/2020.7.33

\title{
Дмитро Спафаров,
}

студент магістратури факультету соиіології і права

Національного технічного університету України

«Київський політехнічний інститут імені Ігоря Сікорського»

\section{ДЕФЕКТ ВІДПОВІДАЧА В АДМІНІСТРАТИВНОМУ ПРОЦЕСІ}

У статті досліджуються особливості адміністративного судочинства, які є причиною того, що саме в адміністративному процесі часто, порівняно з іншими видами судочинства, виникає потреба заміни неналежного відповідача. Також досліджується питання неналежного відповідача, пропонується нове поняття «дефект відповідача», яке визначається як стан правовідносин, що ускладнює процес вибору належного відповідача позивачем, здебільшого зумовлений конкретною обставиною справи.

У процесі дослідження розглядаються конкретні категорії обставин, які ускладнюють процес вибору належного відповідача: ліквідачія або реорганізачія державного органу, його колективність, звільнення посадової особи, яка має бути відповідачем по справі, невідповідність фактичних повноважень державного органу повноваженням, встановленим законом. Щодо відповідних обставин у ході дослідження встановлюються причини їх виникнення, їх вплив на правовідносини в абстрактному розумінні та у конкретному на прикладі конкретної судової справи або певної правової моделі.

У статті розглядається сучасна судова практика, яка склалася в Україні шодо неналежного відповідача, також проведено порівняння з иивільним прочесуальним правом і практикою, яка склалася у иивільному судочинстві щодо належності / неналежності відповідача та його заміни. У роботі також досліджено кониептуальні відмінності в інститутах належної сторони в адміністративному процесуальному праві та у иивільному процесуальному праві.

Відповідно до досліджених у статті особливостей неналежності відповідача, ї причин $i$ судової практики також запропоновано певні законодавчі зміни, які було б доцільно розглянути під час подальших змін адміністративного прощесуального законодавства: пропозиція щодо внесення змін до Кодексу адміністративного судочинства Украйни (далі - КАСУ) в частини зміни визначення «державного органу», включення до обов'язків суду дослідження сторін справи на наявність та здійснення заміни неналежного відповідача, створення нової форми усунення неналежного відповідача шляхом «виключення відповідача».

Ключові слова: адміністративне судочинство, неналежний відповідач, належний відповідач, заміна неналежної сторони, неналежна сторона.

Постановка проблеми. Сфера адміністративного судочинства та іï̈ правове закріплення $є$ одними 3 найбільш дискусійних теоретичних і практичних питань у сфері процесуального права. На відміну від цивільного судочинства, де розглядаються спори між приватними, рівними між собою, особами та кримінального судочинства, специфіка якого практично позбавляє можливості адекватного порівняння його з іншими процесами, оскільки завданням кримінального судочинства є захист держави, суспільства та кожної конкретної особи від кримінальних правопорушень, адміністративне судочинство є унікальним, оскільки однією зі сторін обов'язково є, грубо кажучи, «державний орган».

Якщо ж розглядати це поняття в контексті КАСУ, то воно розкривається через інше - «публічно-правовий спір», що визна- чено у п. 2 ч. 1 ст. 4 КАСУ. Відповідно до цієї норми хоча б одна сторона в адміністративному процесі має здійснювати публічновладні управлінські функції, надавати адміністративні послуги, бути суб'єктом виборчого процесу або процесу референдуму.

Вся унікальність адміністративного судочинства, його зміст і сутність розкриваються через сторін. Наявність такого виду судочинства підкреслює незалежність і відокремленість судової гілки влади від будь-якого впливу, оскільки суд як державний орган має із дотриманням передбачених законом принципів та вимог справедливо, неупереджено, відкрито та прозоро вирішити справу, стороною в якій є держава. Але ж суд - це також держава. В той же час ст. 8 КАСУ чітко встановлює, що всі учасники адміністративного процесу $є$ рівними, а наявність будь-яких привілеїв $є$ не допустимою. Таким чином, 
юридично прирівнюються як учасники процесу, наприклад фізична особа та державний орган у своїх правах та обов'язках, так і учасники адміністративного процесу.

Специфіку адміністративного судочинства також підкреслюють встановлені ч. 1 ст. 5 КАСУ способи захисту, які фактично генерують проблематику, якій присвячена ця робота. Виходячи із вказаного положення, особа може звертатися до суду за захистом своїх прав, обравши спосіб або способи захисту, зазначені в передбаченому законом переліку, сформувати позовні вимоги таким чином, щоб вони відповідали способу захисту та могли у подальшому призвести до позитивного вирішення справи для позивача.

В цьому і полягає суттєва проблема для позивача, оскільки в жодному іншому виді судочинства не постає стільки питань у здавалося б простій та елементарній дії - обранні належного відповідача. Оскільки в адміністративному судочинстві відповідачем зазвичай виступає суб'єкт владних повноважень, то на позивача лягає обов'язок визначення належного відповідача, тобто обрання конкретної особи, державного службовця, органу, відділу, підрозділу, держави загалом тощо, яку буде залучено до справи в якості відповідача.

Проблему визначення належного відповідача поглиблює те, що в Україні відсутня стала судова практика 3 цього питання, більше того, вона варіюється залежно від ледь не конкретного державного органу в якості відповідача та конкретного типу вимоги з боку позивача. Обрання належного відповідача - ледь не найважливіша стадія підготовки та подання позовної заяви поряд із правильним формуванням позовних вимог та обранням способу захисту, оскільки, уникнувши у процесі підготовчого провадження обговорення питання неналежності відповідача, визначення належного відповідача, заміни неналежного відповідача на належного, ймовірної зміни підсудності справи в результаті зміни неналежного відповідача на належного, позивач уникає гаяння істотної кількості часу.

Очевидно, що суд також має бути зацікавленим у тому, щоб позивач визначив відповідача належним чином, оскільки в результаті заміни відповідача або залучення співвідповідача розгляд справи розпочинається з початку, а обговорення в ході судового засідання заміни неналежної сторони віддаляє учасників справи від вирішення справи по суті, а акцент зміщується більше на форму судочинства, ніж на його сутність.
Правове становище відповідача в адміністративному процесі досліджували В.Б. Авер'янов, В.І. Андрєйцев, Ю.П. Битяк, В.В. Копєйчиков, А.В. Бречко та інші вчені, але тема цієї статті окремо не досліджувалася, що підтверджує іï̈ наукову новизну та актуальність.

У цій статті маю на меті проаналізувати інститут неналежного відповідача в адміністративному процесі, встановити причини обрання позивачем неналежного відповідача, запропонувати нове поняття - «дефект відповідача», дати йому визначення, а також запропонувати ймовірні законодавчі зміни.

Виклад основного матеріалу. У процесі визначення відповідача при подачі позовної заяви можуть існувати певні обставини, які можуть завадити позивачеві визначити належного відповідача. Таку обставину можна назвати дефектом відповідача. Дефект відповідача - це стан правовідносин, що ускладнює процес вибору належного відповідача позивачем, здебільшого зумовлений конкретною обставиною справи, зокрема ліквідацією або реорганізацією органу, його колективністю, звільненням посадової особи тощо.

Найбільша кількість подібних обставин виникає саме в процесі адміністративного судочинства, виходячи зі специфіки функціонування державних органів, системи державної служби в Україні, бюрократичних особливостей перетворення державних органів, установ тощо. Серед таких обставин можна зазначити ліквідацію особи відповідача, реорганізацію, звільнення конкретного державного службовця, ліквідацію посади, дублювання повноважень державного органу іншим державним органом, відсутність чітко прописаних повноважень державного органу, колективність особи відповідача.

Одним із дефектів відповідача, який зустрічається найчастіше, є невідповідність фактичних повноважень державного органу положенням законодавства чи дублювання повноважень одного державного органу повноваженнями іншого державного органу. Таким чином, позивач, відображаючи у позовній заяві в якості відповідача конкретний орган, вважаючи, що цей орган очевидно $€$ відповідачем і у цьому не може бути жодних сумнівів, у процесі розгляду справи дізнається, що необхідно залучити співвідповідача, який наділений такими ж повноваженнями, або необхідно наприклад замінити цього відповідача на належного.

Можна припустити, що такий дефект відповідача виникає через те, що в нашій державі система державних органів, їх структура 
і взаємодія є досить бюрократизованими, а законодавство - досить недосконалим i нагромадженим, внаслідок чого у процесі визначення належного відповідача можуть виникати подібні проблеми.

Ще одним із поширених дефектів відповідача є реорганізація чи ліквідація державного органу, тобто учасником правовідносин виступав конкретний державний орган, який, наприклад, на момент подачі позовної заяви взагалі ліквідовано або поділено на декілька державних органів. У такій ситуації позивачеві необхідно детально дослідити правовий акт, яким регламентовано ліквідацію або реорганізацію державного органу, оскільки саме цим актом має визначатися правонаступник перетвореного або припиненого органу. Але де-факто це не так просто, як здається.

Візьмемо за приклад перетворення Державної фінансової інспекції України на Державну аудиторську службу України. До перетворення особа-позивач працювала у Державній фінансовій інспекції України, але її було незаконно звільнено. На момент подачі позовної заяви з вимогою про поновлення на роботі Державна фінансова інспекція України вже перетворена на Державну аудиторську службу України. Особа, дослідивши акти, якими регламентовано реорганізацію колишнього державного органу, зазначає в якості відповідача Державну аудиторську службу України та конкретного державного службовця - свого керівника, який видавав наказ про звільнення позивача. В цій ситуації позивачеві вдалося уникнути помилки, він не зазначив в якості відповідача реорганізований орган, здавалося б, справу зроблено. Але, як виявилося пізніше, його колишній керівник також звільнився, і на момент розгляду справи в суді він не є суб'єктом владних повноважень.

У наведеній ситуації це не потягло за собою заміни неналежного відповідача, оскільки в цьому випадку в якості відповідача необхідно було зазначити виключно новоутворений орган без зазначення конкретної особи, адже орган вже не існує, тому і всі посади та посадові особи його також не існують. Але в цьому випадку виникла інша ситуація - суддя відмовлявся розглядати справу, оскільки у справі був неналежний відповідач - колишній керівник. Суддя переносив засідання за засіданням, аргументуючи це вимогою до позивача якось виключити зі справи неналежного відповідача.

«Якось виключити», а не висловити згоду на заміну неналежного позивача належним, тому що КАСУ не передбачає можливості виключення неналежного від- повідача. При розгляді цієї справи склалася неоднозначна та унікальна ситуація, яка суттєво затягнула процес. Оскільки в учасниках справи вже був належний відповідач - Державна аудиторська служба України, міняти колишнього керівника позивача не було на кого, його необхідно було виключити. Суд же прийняти рішення про виключення відповідача не міг, він міг прийняти рішення про заміну неналежного відповідача на належного. Таким чином, сторони виявилися у «юридичній пастці». Через пів року суддя все ж прийняв рішення по справі, не зважаючи на те, що одним із відповідачів у справі була просто фізична особа. Варто також зазначити, що позивача в цій справі було незаконно звільнено під час люстрації.

Крім того, що у процесі розгляду цієї справи також виник додатковий дефект відповідача - звільнення державного службовця. Виявилася й ще одна проблема - недосконалість процесуального законодавства. Відповідно до КАСУ суд не вирішує питання належності сторін до відкриття провадження, а неналежну сторону може бути замінено до винесення рішення по справі, але у справі виявилося два відповідача, яких зазначив позивач у позовній заяві: єдиний належний відповідач - Державна аудиторська служба України та неналежний відповідач - колишній керівник, замінити якого було не можливо, оскільки належний відповідач вже $є$ учасником справи.

Під час визначення відповідача часто виникає проблема з тим, що позивач зазначає в якості відповідача посадову особу органу, коли відповідачем має виступати орган. Результат розгляду справи, в якій позивачем було визначеного неналежного відповідача, висвітлено у Постанові Верховного Суду в складі колегії суддів Касаційного адміністративного суду від 26 грудня 2019 року по справі № 724/716/16-а.

Фабула: постановою від 5 травня 2016 року № 11 особу 1 було визнано винною у вчиненні адміністративного правопорушення за ст. 53-1 КУпАП, на неї накладено адміністративне стягнення у вигляді штрафу в розмірі 170,00 грн за самовільне зайняття земельної ділянки площею 0,0021 га, яка перебуває у користуванні іншої особи, шляхом встановлення металевої сітки з металевими стовпчиками.

Винесенню оскаржуваної постанови передувало складання акту перевірки дотримання вимог земельного законодавства від 26 квітня 2016 року та протоколу про адміністративне правопорушення від 26 червня 2016 року № 00011, в яких було зафіксовано 
викладене вище порушення вимог земельного законодавства.

Так, Особа 1 звернулася до суду з позовом до державного інспектора, в якому просила скасувати постанову, оскільки були відсутні будь-які докази його вини, його безпідставно притягнуто до адміністративної відповідальності. Особа також обгрунтовувала незаконність постанови тим, що розмежування ділянок ним було здійснено ще у 2013 році до передачі ділянки в користування іншій особі.

Перша інстанція задовольнила позов Особи 1, а апеляційна інстанція відмовила у задоволенні апеляційної скарги Держсільгоспінспекції. Держсільгоспінспекцією було подано касаційну скаргу з проханням скасувати рішення суду першої та апеляційної інстанції, обгрунтовуючи скаргу тим, що постанова про накладення адміністративного стягнення була виписана відповідно до закону.

Верховний Суд скасував рішення першої та апеляційної інстанцій та відправив справу на новий розгляд у першу інстанцію, аргументуючи це тим, що відповідно до норм матеріального права відповідні адміністративні справи розглядає центральний орган виконавчої влади, який реалізує державну політику зі здійснення державного нагляду (контролю) у сфері охорони навколишнього природного середовища, раціонального використання, відтворення і охорони природних ресурсів. Посадові ж особи лише виступають від імені органу.

Також формулювання, які мають місце в КУ ПАП, наприклад «від імені центрального органу виконавчої влади розглядати справи про адміністративні правопорушення і накладати адміністративні стягнення мають право Головний державний інспектор України 3 охорони навколишнього природного середовища та його заступники» додатково підтверджують те, що позов має бути подано до органу, а не до посадової особи.

Враховуючи норми матеріального права, а також те, що судом не було виконано свого обов'язку щодо встановлення належності сторін і за потреби ініціювання заміни неналежних сторін, і те, що по справі відсутні докази того, що суд пропонував позивачеві здійснити заміну неналежного відповідача, Верховним Судом прийнято рішення про скасування рішень попередніх двох інстанцій, оскільки справа розглядалася з неналежним відповідачем - посадовою особою.

Можна зробити висновок, що у процесі визначення позивачем належного відповідача може виявитися певна кількість обставин, які стосуються відповідача, які можуть завадити позивачеві правильно визначити відповідача. Такі обставини можна назвати дефектом відповідача. 3 причин виникнення такого явища та його сильної розповсюдженості саме в адміністративному процесі можна назвати відсутність сталої судової практики, на яку могла б спиратися особа в процесі визначення відповідача по справі, також часті організаційно-правові зміни у державному секторі, тобто перетворення державних органів і недосконалість законодавства, а саме відсутність систематичного та комплексного підходу під час регламентації повноважень державних органів, внаслідок чого може виникати дублювання повноважень, або невідповідність легальних повноважень реальним тощо.

Що стосується вирішення цієї проблеми, то найбільш очевидним здається рішення про усунення обов'язку позивача визначати конкретного відповідача по справі, враховуючи специфіку адміністративного судочинства, в якому найчастіше відповідачем виступає суб́'єкт владних повноважень. Тобто, можна уявити таку модель адміністративного процесу, за якої позивач буде зазначати в якості відповідача державу Україна, а на наступному етапі суд, виходячи 3 сутності правовідносин, матеріального права, позовних вимог і способу захисту, буде визначати належного відповідача, або цю функцію може виконувати окремий державний орган чи відділ певного органу або підрозділ. Позивача не дуже цікавить, хто саме буде виступати відповідачем по справі, він звертається виключно за захистом своїх прав. Відповідачем же у будь-якому випадку буде суб'єкт владних повноважень, тобто орган, в особі якого діє держава.

3 метою порівняння та аналізу можна також дослідити положення Цивільного процесуального кодексу України, а саме ч. 2 ст. 48, де визначено, що позивачем і відповідачем можуть бути фізична, юридична особа, а також держава, в той час коли у КАСУ визначено, що відповідачем є суб'єкт владних повноважень, який визначено у ст. 4 КАСУ як орган державної влади (в тому числі без статусу юридичної особи), орган місцевого самоврядування, їх посадова чи службова особа, інший суб'єкт при здійсненні ними публічно-владних управлінських функцій на підставі законодавства, в тому числі на виконання делегованих повноважень, або надання адміністративних послуг.

Результат такого підходу відображено у постанові Великої Палати Верховного Суду від 25 березня 2020 року по справі № 641/8857/17. Цю постанову було винесено по цивільній справі, але вона опосередковано стосується досліджуваної теми, 
і підхід, який висвітлено у вказаній вище постанові, може бути використано в адміністративному процесі.

Так, особа звернулася 3 позовом до Харківської місцевої прокуратури № 5, прокуратури Харківської області, Державної казначейської служби України про визнання дій незаконними, відшкодування моральної шкоди, завданої незаконними діями і бездіяльністю органів дізнання, досудового слідства, прокуратури і суду, оскільки кримінальне провадження було закрито, а обвинувальний вирок винесено іншій особі.

Перша інстанція відмовила у задоволенні позову повністю, апеляційна інстанція задовольнила частково в частині визнання дій незаконними, в частині стягнення моральної шкоди було відмовлено. Особа подала касаційну скаргу, в якій посилалася на неправильне застосування судами норм матеріального та процесуального права. Особі було відмовлено у задоволенні касаційної скарги, оскільки моральна шкода відшкодовується однократно, а особа вже отримала 10000 грн компенсації за незаконне утримання під вартою під час кримінального провадження.

Крім цього, касаційний суд висловив думку, відповідно до якої держава діє в цивільних відносинах на рівних правах 3 іншими учасниками цих відносин (ч. 1 ст. 167 ЦК України). Держава набуває і здійснює цивільні права та обов'язки через органи державної влади в межах їхньої компетенції, встановленої законом (ст. 170 ЦК України).

Позивачем і відповідачем можуть бути фізичні і юридичні особи, а також держава (ч. 2 ст. 48 ЦПК України). Державу представляють відповідні органи державної влади в межах їх компетенції через свого представника (ч. 4 ст. 58 ЦПК України). Отже, уцивільному судочинстві державабереучасть у справі як сторона через відповідний ії орган, наділений повноваженнями саме у спірних правовідносинах, зокрема і представляти державу в суді (постанови Великої Палати Верховного Суду від 20 листопада 2018 року у справі № 5023/10655/11 (провадження № 12-161 гс 18) (пункт 6.22), від 21 серпня 2019 року у справі № 761/35803/16-ц (постанова № 14-316 цс 19) (пункт 33), від 18 грудня 2019 року у справі № 688/2479/16-ц (провадження № 14/447 цс 19) (пункт 28), здебільшого орган, діями якого завдано шкоду.

Враховуючи все вказане вище, суд зробив висновок про те, що залучення чи незалучення до участі в таких категоріях спорів Державної казначейської служби чи їі тери- торіального органу не впливає на правильність визначення належного відповідача у справі, тому що відповідачем є держава, а не Державна казначейська служба України. Можна припустити, що такий підхід може бути використано і в адміністративному судочинстві, враховуючи те, що в якості відповідача в адміністративному судочинстві зазвичай виступає суб'єкт владних повноважень, тобто представник держави.

Не зовсім зрозуміло, чому у цивільному судочинстві суд висловлює позицію, що залучення чи незалучення конкретного органу до справи в якості відповідача не впливає на правильність визначення відповідача у справі, а в адміністративному судочинстві суди апеляційної та касаційної інстанцій скасовують попередні рішення на підставі того, що позов було подано, наприклад, не до державного органу, а до посадової особи.

Нерідко в публічно-правових спорах на етапі подання позову позивачу важко передбачити плинність судової практики судів вищих інстанцій в частині того, хто має бути належним відповідачем. Відомими є приклади щодо повернення надміру сплачених податків. У цій сфері податки сплачуються до бюджету, який адмініструється Державною казначейською службою, але податкова звітність подається до органів Державної податкової служби (яка неодноразово реорганізовувалася).

Фактично ж гроші отримує та повернути їх при зайвій сплаті має держава або територіальна громада, а не конкретний суб'єкт владних повноважень. Звісно, що для позивача (фізичної особи-підприємця, юридичної особи) реорганізації державних органів, зміна їх компетенції або плинність практики не повинні створювати проблему для реалізації його прав та їх судового захисту. Інакше право на справедливий суд виглядає ілюзорним. Особливо в ситуаціях, коли декілька інстанцій неправильно розібрались в суб'єктному складі спору, а після кількарічного диспуту всі рішення в справі скасовуються через неправильний вибір відповідача.

Виключення з КАСУ обов’язку позивача визначати конкретного відповідача по справі може бути важко реалізувати та виправдати, це може бути сприйнято як надто радикальна для нашої системи судочинства новація, тому, починаючи з більш лояльних змін, можна почати посилено працювати над формуванням сталої позиції Верховного Суду 3 питання визначення належного відповідача 3 метою уникнення постійних дискусій із цього питання у правовому середовищі. 


\section{Висновки}

Дефектом відповідача в адміністративному процесі є стан правовідносин, що ускладнює процес вибору належного відповідача позивачем, здебільшого зумовлений конкретною обставиною справи. Враховуючи досліджені в цій статті дефекти відповідача та причини їх виникнення, можна припустити, що включення у визначення «суб'єкт владних повноважень» у ст. 4 КАСУ таких суб'єктів як «службова, посадова особа, інший суб'єкт при здійсненні ними публічно-владних управлінських функцій на підставі законодавства» себе не виправдало у зв'язку з виникненням у подальшому колосальної кількості скасованих судових рішень через те, що справу було вирішено за відсутності належного відповідача по справі, оскільки відповідачем необхідно було визначити орган, а не посадову особу чи навпаки. Можливо, необхідно обмежити «суб'єкта владних повноважень» органами державної влади та місцевого самоврядування. Таким чином, можливо буде виключити один із найрозповсюдженіших дефектів відповідача в адміністративному процесі.

Оскільки в судовій практиці неодноразово висловлювалася позиція, що визначення відповідача є правом позивача і він не завжди може визначити належного відповідача, можна також запропонувати закріпити у КАСУ обов'язок замість права суду здійснювати заміну неналежного відповідача на належного за згодою відповідача. Оскільки в ч. 2 ст. 180 КАСУ визначено, що у підготовчому засіданні суд вирішує питання про «заміну неналежного відповідача», доцільніше встановити обов'язок суду здійснювати заміну з метою впорядкування адміністративного судочинства та попередження скасувань касаційною інстанцією рішень першої та апеляційної інстанцій.

У статті також було описано юридичну ситуацію, яка опосередковано стосується теми статті - неможливість виключення відповідача. Коли у процесі розгляду справи виникає така ситуація, що у справі вже є два відповідачі (належний і неналежний), суд не може застосувати заміну неналежного відповідача, оскільки заміна передбачає, що замість одного позивача у справу включається інший, але і виключити неналежного відповідача суд також не може, оскільки відсутній такий процесуальний механізм. Отже, пропоную врахувати необхідність включення такого механізму при подальших змінах процесуального законодавства.
Під час внесення змін до законодавства пропоную внести такі зміни:

1) викласти визначення «суб’єкт владних повноважень» у ст. 4 КАСУ такій редакції: «суб'єкт владних повноважень - орган державної влади (у тому числі без статусу юридичної особи) та орган місцевого самоврядування»;

2) включити до обов'язків суду дослідження сторін справи на наявність неналежних і здійснення заміни неналежного відповідача;

3) КАСУ доповнити ст. 48-1, яку викласти в такій редакції:

«Стаття 48-1. Виключення неналежного відповідача

1. Якщо позов подано до декількох відповідачів і судом встановлено неналежність одного 3 відповідачів, суд виключає неналежного відповідача та переводить позовні вимоги від неналежного відповідача до належного. Про виключення неналежного відповідача суд постановляє ухвалу, що може бути оскаржена.

2. Якщо вирішення справи може вплинути на права та обов'язки неналежного відповідача, суд залучає неналежного відповідача в якості третьої особи без самостійних вимог».

Зважаючи на поширеність ситуацій із дефектом відповідача, перманентні адміністративні реформи та перейменування, плинність кадрів у публічному секторі, а також сферу адміністративної юстиції, подальші дослідження порушеної проблеми $€$ перспективними та актуальними.

\section{Список використаних джерел:}

1. Кодекс адміністративного судочинства України : Закон України від 06.07.2005 № 2747IV. Відомості Верховної Ради України (ВВР), 2005, № 35-36, № 37, ст. 446.

2. Постанова Верховного суду у складі колегії суддів Касаційного адміністративного суду від 26 грудня 2019 року по справі № 724/716/16-а // [Електронний ресурс]. Режим доступу: http://reyestr.court.gov.ua/Review/ 86636182.

3. Постанова Великої Палати Верховного Суду від 25 березня 2020 року по справі № 641/8857/17 // [Електронний ресурс]. Режим доступу: http://reyestr.court.gov.ua/Review/ 88570901 .

4. Цивільний кодекс України : Закон України від 16.01.2003 № 435-IV. Відомості Верховної Ради України (ВВР), 2003, №№ 40-44, ст. 356.

5. Цивільний процесуальний кодекс України : Закон України від 18.03.2004 № 1618-IV. Відомості Верховної Ради України (ВВР), 2004, № 40-41, 42, ст. 492. 
Dmytro Spatharov. Defendant defect in administrative proceedings

The article explores the features of administrative proceedings, which are the reason that in the administrative process often, in comparison with other types of proceedings, there is a need to replace an improper defendant. It also examines the issue of improper defendant, proposes a new concept of "defendant defect", which is defined as the state of legal relations, complicating the process of choosing the appropriate defendant by the plaintiff, due, as a rule, to the specific circumstances of the case.

The article examines specific categories of circumstances that complicate the process of selecting the proper defendant: liquidation or reorganization of the state body, its collectiveness, dismissal of the official who must be the defendant in the case, inconsistency of the actual powers of the state body with the law. Under the relevant circumstances, the article establishes the reasons for their occurrence, their impact on legal relations in the abstract sense and in the specific, on the example of a particular case or a particular legal model.

The article discusses modern judicial practice that has developed in Ukraine regarding an improper defendant, also compares it with civil procedural law and the practice that has developed in civil proceedings on the defendant properness / improperness and its replacement. The article also explores conceptual differences in the institutions of a proper party in administrative procedural law and in civil procedural law.

According to the features of the defendant's impropriety, its causes and judicial practice, examined in the article, certain legislative changes are also proposed, which would be advisable to consider during further changes in the administrative procedural legislation, including: a proposal to amend the Code of Administrative Procedure of Ukraine (hereinafter - CASU), including changes to the definition of "state body", inclusion in the court's duties of investigation of the parties for the impropriety and replacement of an improper defendant, creation of a new form for eliminating of an improper defendant - "exclusion of the defendant".

Key words: administrative process, improper defendant, proper defendant, improper party replacement, improper party. 